\title{
Pengaruh Corporate Governance Terhadap Agency Cost Pada Perusahaan Manufaktur Yang Terdaftar Di BEI
}

\author{
Alya Nisrina Hafsyah ${ }^{1}$, Mega Mersela ${ }^{2}$, dan Henny Setyo Lestari ${ }^{3}$ \\ ${ }^{1,2,3}$ Faculty of Economic and Business, Trisakti University \\ Email Address: \\ alyanisrinah@gmail.com; merselamega@gmail.com; henny_setyo_lestari@trisakti.ac.id
}

\begin{abstract}
This study aims to determine the effect of corporate governance on agency costs. The sample used for this research is manufacturing companies listed on the Indonesia Stock Exchange during the 2016-2020 period, which total 66 companies. The technique for taking samples in this research is purposive sampling and panel data regression analysis methods. The independent variables used are board size, board independent, management ownership and foreign ownership and the control variables are leverage, firm size, firm performance with agency cost as the dependent variable.
\end{abstract}

Keywords: agency cost, board independent, board size, firm performance, firm size, foreign ownership, management ownership leverage.

\begin{abstract}
Abstrak: Penelitian ini tujuannya mengetahui pengaruh corporate governance terhadap agency cost. Penggunaan sampel untuk penelitian ini yaitu perusahaan manufaktur yang tercatat di Bursa Efek Indonesia selama periode 2016-2020 yang jumlahnya 66 perusahaan. Teknik untuk pengambilan sampel dalam penelitian, adalah purposive sampling dan metode analisa regresi data panel. Variabel bebas yang dipakai yakni board size, board independent, management ownership dan foreign ownership serta variabel kontrol yakni leverage, firm size, firm performance dengan agency cost sebagai variabel dependen.
\end{abstract}

Kata kunci: agency cost, board independent, board size, firm performance, firm size, foreign ownership, management ownership leverage.

\section{PENDAHULUAN}

Dalam masa pasca krisis ekonomi, Indonesia berada dalam tahap yang memprihatinkan yakni menghadapi permasalahan pemulihan perekonomian dan ancaman kelangsungan hidup perusahaan. Untuk segera bangkit dari krisis sekaligus mempertahankan kelangsungan hidup, para pelaku dunia usaha harus mengubah cara mereka melakukan dan mengelola bisnis. Ditambah lagi dengan datangnya era globalisasi dimana pasar akan semakin kompetitif, maka perubahan yang fundamental dalam penerapan tata kelola perusahaan (corporate governance) mutlak dilakukan. Perspektif hubungan 
keagenan merupakan dasar yang digunakan untuk memahami corporate governance (Darmawati dalam Sayidah, 2017).

Dalam teori keagenan, hubungan keagenan muncul ketika satu orang atau lebih (principal) Corporate Governance (tata kelola perusahaan) merupakan suatu proses dan tata kelola yang digunakan oleh organ perusahaan untuk meningkatkan keberhasilan usaha dan akuntabilitas perusahaan yang menjelaskan hubungan antara berbagai partisipan dalam perusahaan. Pada prinsipnya Corporate Governance (tata kelola perusahaan) menyangkut kepentingan para pemegang saham yaitu dengan memberikan perlindungan dan jaminan hak terhadap stakeholder, termasuk di dalamnya yaitu shareholders, lenders, employers, executives, government, customers dan stakeholders yang lain (Mappanyukki et al., 2016).

Pada bulan April 2021 didapati sector pertambangan dengan gerak Indeks Harga Saham Gabungan (IHSG) sector tambang sempat lesu bahkan melemah dan merosot hingga $1.35 \%$. Hal ini karena adanya kasus B117 yang dipengaruhi tren kenaikan kasus COVID19 di Indonesia. Namun IHSG pada bulan Mei 2021 meunjukkan sektor tambang berada di level tertinggi. Sebanyak 301 saham menguat sehingga mengangkat IHSG. Sector tambang naik 2,22\% dan dicatat sebagai penguatan terbesar. (www.liputan6.com)

Dalam beberapa tahun terakhir, ada banyak penelitian yang meneliti konflik manfaat yang timbul antara pemegang saham yang tersebar dan manajer yang berkuasa ketika struktur manajemen diubah. Hasil penelitian menunjukkan bahwa perusahaan perlu menghapus segala sumber inefisiensi organisasi dan membangun mekanisme yang melindungi kekayaan pemegang saham (Damodaran 2014). Menurut Core et al. dalam (Gray et al., 2019), perusahaan cenderung menghadapi tingkat biaya agensi yang lebih tinggi dengan struktur tata kelola perusahaan yang buruk, di mana tim manajemen yang kuat dapat melakukan tindakan yang merugikan keuntungan pemegang saham, untuk mencapai kepentingan manajerial. Salah satu penelitian penting di negara maju yang layak disebut adalah Ang et al. dalam (Singh dan Davidson, 2018), yang menggunakan sampel 1708 perusahaan kecil AS untuk mengukur biaya agensi di bawah struktur kepemilikan yang berbeda. Menggunakan dua rasio efisiensi alternatif: rasio biaya operasional dan rasio pemanfaatan aset, untuk mengukur biaya agensi, penelitian ini menemukan bahwa biaya agensi meningkat ketika orang luar mengelola perusahaan. Selain itu, biaya agensi menurun karena kepemilikan lebih terkonsentrasi. Selain itu, untuk perusahaan kecil, pemantauan eksternal oleh bank dapat mengurangi biaya keagenan, karena bank akan memimpin dan mengendalikan perusahaan agar beroperasi lebih efisien. Insentif pemantauan bank dihitung dengan jumlah bank yang digunakan oleh perusahaan dan lamanya hubungan antara perusahaan dan bank utamanya.

Tulisan ini dilatarbelakangi oleh karakteristik teori keagenan dari berbagai jenis dan tingkat tata kelola perusahaan dalam praktiknya didorong oleh budaya dan sistem hukum. Oleh karena itu, tujuan dari makalah ini adalah untuk menyelidiki hubungan antara tata kelola perusahaan dan biaya keagenan dengan menganalisis secara empiris faktor-faktor penentu biaya keagenan di perusahaan yang terdaftar di Indonesia, pasar yang dinamis dengan sistem tata kelola perusahaan yang rumit karena efek transformasi struktur politik dan ekonomi.

Penelitian ini bertujuan untuk mengetahui keterkaitan corporate governance (tata kelola perusahaan) yang diterapkan dalam suatu perusahaan dengan masalah agensi yang 
akan menimbulkan agency cost. Dalam konteks perusahaan, masalah agensi lebih menaruh perhatian pada hubungan antara manajer dengan pemegang saham yang tidak terlibat di manajemen, sedangkan corporate governance melihat hubungan antara manajer dan seluruh stakeholders perusahaan. Corporate governance (tata kelola perusahaan) memiliki prinsip adanya transparansi, keterbukaan dan pertanggungjawaban sehingga perusahaan yang baik semestinya akan dapat mengurangi masalah agen. Melihat keterkaitan antara masalah agensi dan corporate governance (tata kelola perusahaan) tersebut, nampaknya efektifitas mekanisme pengurang masalah agensi akan dipengaruhi oleh bagaimana praktik corporate governance (tata kelola perusahaan) di masing - masing perusahaan".

\section{KAJIAN TEORI}

Corporate Governance. Corporate governance merupakan suatu mekanisme pengelolaan yang didasarkan pada teori keagenan. Penerapan konsep corporate governance diharapkan memberikan kepercayaan terhadap agen (manajemen) dalam mengelola kekayaan pemilik (investor), dan pemilik menjadi lebih yakin bahwa agen tidak akan melakukan suatu kecurangan untuk kesejahteraan agen (Yusuf dan Said, 2018).

Corporate governance berkaitan dengan bagaimana para investor yakin bahwa para manajer akan memberikan keuntungan bagi mereka, yakin bahwa manajer tidak akan mencuri/menggelapkan atau menginvestasikan dana atau modal yang telah ditanamkan oleh para investor, dan berkaitan dengan bagaimana para investor mengontrol para manajer (Retnoningsih dan Mahanani, 2019).

Ukuran Dewan (Board Size). Besar kecil atau ukuran dewan direksi mempengaruhi bagaimana proses operasional perusahaan berjalan. Dewan direksi merupakan orang yang diberikan mandat untuk menjalankan operasional di dalam perusahaan. Dewan direksi bertanggungjawab penuh atas segala bentuk operasional dan kepengurusan perusahaan dalam rangka melaksanakan kepentingan pencapaian tujuan perusahaan. (Krisnauli; Hadiprajitno, 2014).

Dewan Independen (Independence of Board Member). Dewan independen adalah dewan tidak memiliki jabatan langsung ataupun mempunyai relasi dengan perusahaan tersebut sehingga pengambilan keputusan dari dewan komisaris independen biasanya bersifat netral dan menghindari benturan kepentingan antara prinsipal dengan pengelola, dengan kata lain keberadaan dewan komisaris independen dapat membantu memonitor perusahaan agar pengelolaan aset perusahaan dapat menjadi lebih efisien dan mengurangi agency cost (Ezra et al., 2016).

Kepemilikan Manajerial (Management Ownership). Kepemilikan manajerial adalah proporsi pemegang saham dari pihak manajemen yang secara aktif ikut dalam pengambilan keputusan perusahaan. Kepemilikan manajerial yang besar di dalam perusahaan akan efektif untuk mengawasi aktivitas perusahaan (Pujiati dan Widanar, 2019). Kepemilikan manajerial akan mendorong manajemen untuk meningkatkan kinerja perusahaan, karena mereka juga memiliki perusahaan. Semakin besar proporsi kepemilikan manajemen maka manajemen 
cenderung berusaha lebih giat untuk kepentingan pemegang saham dalam meningkatkan kinerja perusahaan. Peningkatan kinerja perusahaan ini akan mengindikasikan tingginya rasio perputaran asset. Pihak manajer yang memiliki saham perusahaan cenderung melakukan strategi untuk meningkatkan kinerja perusahaan dalam jangka Panjang (Sulthon, 2018).

Kepemilikan Asing (Foreign Ownership). Struktur kepemilikan asing merupakan proporsi saham biasa perusahaan yang dimiliki oleh perorangan, badan hukum, pemerintah, serta bagian-bagiannya yang berstatus luar negeri (Prananda dan Triyanto, 2020). Menurut (Melmusi, 2016) mendefinisikan kepemilikan asing sebagai investor/pemegang saham yang berasal dari negara lain (domisili dan legal pendirian perusahaan di luar negeri), dalam jumlah yang cukup besar digunakan untuk mengendalikan perusahaan tersebut.

Selain itu, (Febrianny et al., 2020) mendefinisikan kepemilikan asing sebagai presentase saham yang dimiliki investor asing dan memiliki peran penting dalam mengawasi manajemen perusahaan. Adapun (Kusumasari et al., 2018) mengidentifikasi kepemilikan asing sebagai kepemilikan saham yang dimiliki oleh perusahaan multinasional.

Penelitian ini mengkaji bagaimana pengaruh variabel independen yang terdiri dari Board Size, Board Independence, Managerial Ownership, Foreign Ownership dan Leverage, Firm Size dan Firm Performance sebagai variabel kontrol terhadap dependen variabelnya yaitu Agency Cost. Kerangka konseptual dari penelitian ini dapat dibentuk seperti gambar berikut: 
INDEPENDENT

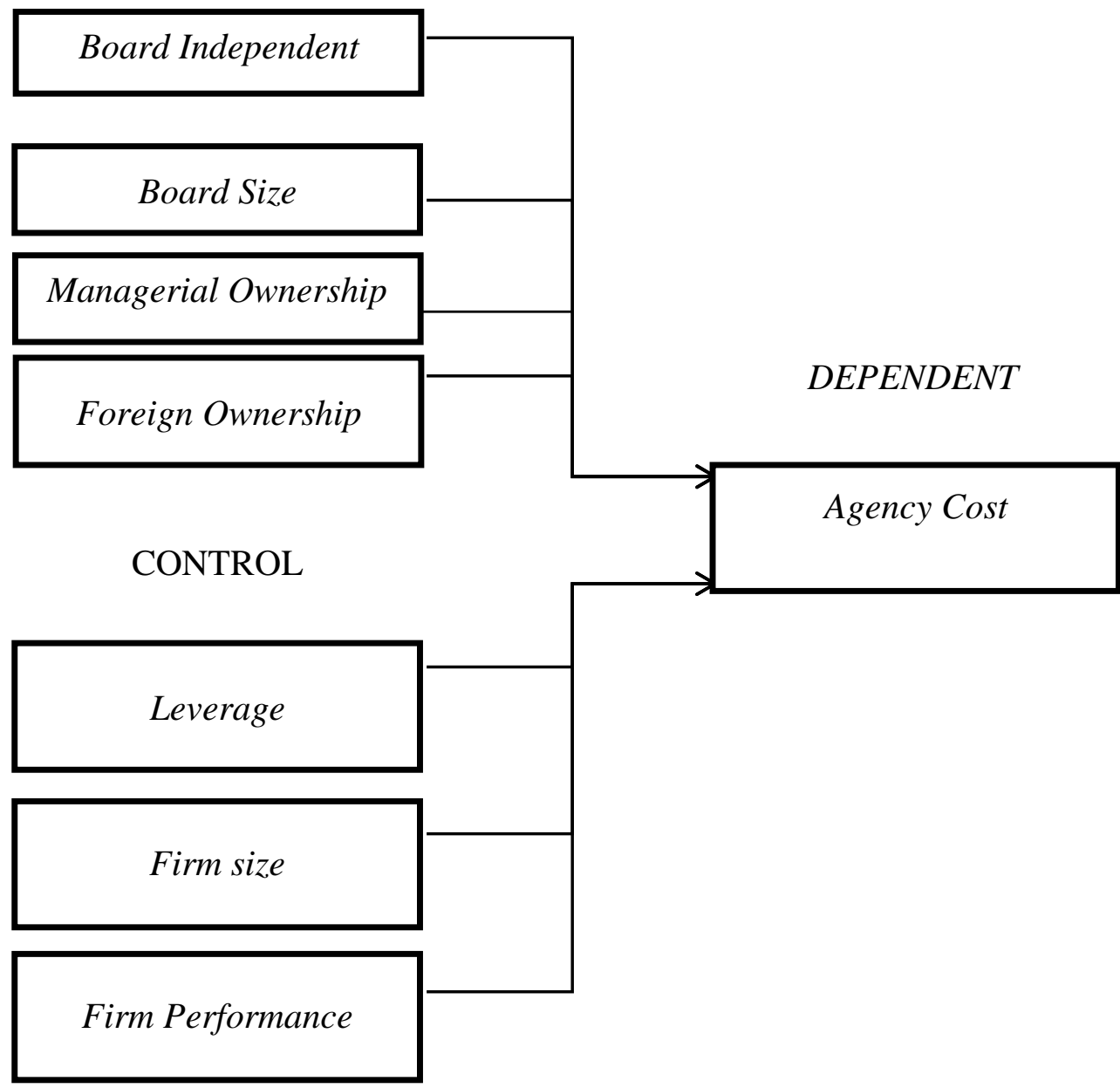

Gambar 1. Model Penelitian

Board Size dan Agency Cost. Penelitian (Čalopa et al., 2020) menyatakan bahwa dewan direksi dalam suatu perusahaan akan menentukan kebijakan yang akan diambil atau strategi perusahaan secara jangka pendek maupun jangka panjang. Oleh karena itu proporsi dewan (baik dewan direksi maupun dewan komisaris) berperan dalam kinerja perusahaan dan dapat meminimalisasi kemungkinan terjadinya permasalahan agensi dalam perusahaan. Jumlah dewan direksi yang semakin besar akan menimbulkan ketidakefektifan dalam manajemen mengimplementasikan kebijakan dan menngkatkan penjualan.

(Chaudhary, 2021) yang menemukan bahwa ukuran dewan yang tinggi akan menimbulkan biaya keagenan yang tinggi juga. Hasil ini dikarenakan oleh kurangnya efisiensi di dalam dewan direksi. Jumlah dewan direksi yang jumlahnya lebih kecil, lebih efektif bagi perusahaan yang nantinya akan berdampak pada kepercayaan prinsipal kepada agen. Dari uraian di atas dapat dirumuskan hipotesis sebagai berikut: 
H1: Terpadapat pengaruh Board Size terhadap Agency Cost.

Board Independence dan Agency Cost. Menurut penelitian (Hamdan, 2018) berpendapat bahwa dewan komisaris independen yang melakukan pemantauan terhadap manajemen turut mengurangi agency cost dalam proses pengelolaan perusahaan. Hal ini sesuai dengan penelitian (Pahi dan Yadav, 2018), (Thi and Elaine, 2017) direktur independen mungkin tidak dapat menyelesaikan fungsi pemantauan mereka dalam tata kelola karena kurangnya keahlian, yang berpotensi menyebabkan masalah keagenan yang lebih besar dan kinerja perusahaan yang lebih buruk. Namun, fokus penelitian ini adalah pada perusahaan yang mayoritas sahamnya dimiliki pemerintah. Oleh karena itu, perumusan hipotesis dapat dituliskan sebagai berikut:

H2: Terdapat pengaruh Board Independence terhadap Agency Cost.

Management Ownership dan Agency Cost. Hasil Riset (Indriastuti et al., 2021) membuktikan bahwa kepemilikan manajer berpengaruh negatif terhadap biaya keagenan dengan menunjukkan bahwa semakin besar jumlah kepemilikan saham manajerial diyakini mampu mengurangi biaya keagenan. Hal ini sejalan dengan penelitian (Rahyuningsih dan Ayem, 2020) menunjukkan bahwa kepemilikan manajerial berpengaruh negatif terhadap tingkat biaya keagenan pada suatu perusahaan. Karena itu, perumusan hipotesis yang ketiga dapat dirumuskan sebagai berikut:

H3: Terdapat pengaruh Management Ownership terhadap Agency Cost.

Foreign Ownership dan Agency Cost. Hasil penelitian (Choi dan Park, 2019) dan (Huu Nguyen et al., 2020). Ketika investor asing berpartisipasi dalam sebuah perusahaan, mereka berusaha untuk belajar tentang banyak pengaturan internasional dan budaya untuk meminimalkan risiko bisnis dan melindungi investasi mereka, sehingga meningkatkan transparansi keuangan. Agar berfungsi dengan sukses dan jujur, perusahaan juga memperoleh standar pada tata kelola internasional dan persyaratan teknologi. Oleh karena itu hipotesanya adalah:

H4: Terdapat pengaruh Foreign Ownership terhadap Agency Cost.

\section{METODELOGI}

Rancangan Penelitian. Penelitian yang dilakukan ini bertujuan untuk menguji hipotesis (hypothesis testing) dari variabel independen yaitu ukuran dewan, dewan independensi, kepemilikan manajemen, kepemilikan pemerintah, dan kepemilikan asing terhadap variabel dependen yaitu biaya agensi. Penelitian ini menganalisis perusahaan sektor manufaktur yang terdaftar di Bursa Efek Indonesia selama periode tahun 2016-2020. Data yang digunakan dalam penelitian ini adalah data sekunder yang didapat dari website resmi Bursa Efek Indonesia (www.idx.co.id). 
Berdasarkan uraian diatas, jenis penelitian hipotesis yang digunakan peneliti, yaitu dengan melakukan suatu uji mengenai hubungan terhadap variable yang satu dengan variable lainnya sesuai dengan variable yang telah dijabarkan atau ditetapkan. Penelitian ini menggunakan data kuantitatif yang ditarik dari BEI, sehingga data dapat dikategorikan sebagai sekunder dengan menggunakan laporan keuangan perusahaan pada periode waktu yang dipakai adalah data regresi dat panel, yaitu tahun 2016-2020 yang terdaftar pada web Bursa Efek Indonesia yang sah serta alamat web dari setiap perushaan.

Kumpulan nformasi yang terkumpul akan diolah dengan software Eviews 10. Hasil dari uji akan dijadikan sebagai dasar dalam menarik kesimpulan pengaruh dari Board Size, Board Independence, Managerial Ownership, Foreign Ownership dan variable kontrol (Leverage, Firm Size, dan Firm Performance) terhadap Agency Cost.

Variabel dan Pengukuran. Variabel dan pengukuran pada penelitian ini dipergunakan dalam menentukan korelasi antara variabel bebas dan tergantung. Berikut adalah pengukuran untuk tiap-tiap variabel.

Tabel 1. Pengukuran Variabel

\begin{tabular}{|c|c|c|c|}
\hline $\begin{array}{c}\text { Jenis } \\
\text { Variabel }\end{array}$ & $\begin{array}{c}\text { Nama } \\
\text { Variabel }\end{array}$ & Simbol & Pengukuran \\
\hline $\begin{array}{c}\text { Variabel } \\
\text { Dependen }\end{array}$ & Agency cost & $\mathrm{AC}$ & Asset turnover \\
\hline \multirow{4}{*}{$\begin{array}{c}\text { Variabel } \\
\text { Independen }\end{array}$} & Board Size & $\begin{array}{l}\text { BOARD } \\
\text { SIZE }\end{array}$ & Jumlah anggota dewan direksi persahaan \\
\hline & $\begin{array}{c}\text { Board } \\
\text { Independence }\end{array}$ & NONEX & persentase direktur non-eksekutif \\
\hline & $\begin{array}{l}\text { Management } \\
\text { Ownership }\end{array}$ & $\begin{array}{c}\text { MNG_O } \\
\text { WNERS } \\
\text { HIP }\end{array}$ & $\begin{array}{c}\text { Persentase saham yang dimiliki oleh semua } \\
\text { tim manajemen }\end{array}$ \\
\hline & $\begin{array}{l}\text { Foreign } \\
\text { Ownership }\end{array}$ & $\begin{array}{c}\text { FR_OW } \\
\text { NERSHI } \\
\text { P }\end{array}$ & $\begin{array}{l}\text { Persentase saham yang dimiliki oleh } \\
\text { investor asing }\end{array}$ \\
\hline \multirow{3}{*}{$\begin{array}{l}\text { Variabel } \\
\text { Kontrol }\end{array}$} & Leverage & $\begin{array}{l}\text { FIRMSIZ } \\
\qquad \mathrm{E}\end{array}$ & Logaritma dari total asset \\
\hline & Firm Size & $\begin{array}{c}\text { DEBT_E } \\
\text { QUITY }\end{array}$ & Total debt to equity \\
\hline & $\begin{array}{c}\text { Firm } \\
\text { Performance }\end{array}$ & ROA & $\frac{\text { Net profit }}{\text { Total asset }}$ \\
\hline
\end{tabular}

Metode Pengukuran Data. Pelaksanaan penelitian ini menggunakan pengumpulan informasi kategori data sekunder, yakni didapat bukan secara langsung melainkan secara online dari www.idx.co.id. Untuk pengumpulannya peneliti menggunakan metode 
dokumentasi dari website Bursa Efek Indonesia serta laporan tahunan dari masing-masing perusahaan manufaktur selama periode 2016-2020.

Metode Pengambilan Sampel. Purposive sampling merupakan metode pengambilan sampel yang dipilih atas dasar kesesuaian data dengan kriteria dan kebutuhan penelitian. Atau Purposive sampling yaitu teknik sampling yang digunakan oleh peneliti jika peneliti mempunyai pertimbangan-pertimbangan tertentu dalam mengambil sampelnya. Metode ini menghasilkan kualitas sampel yang tinggi karena sumber yang akan diolah adalah sumber yang telah sesuai dengan kriteria dan lebih relevan. Cara ini mudah dan murah untuk dilaksanakan. Kriteria dari sampel penelitian ini adalah: (1) Perusahaan manufaktur yang terdaftar di Bursa Efek Indonesia selama periode 2016-2020. (2) Perusahaan yang tidak terdaftar selama periode penelitian 2016-2020. (3) Perusahaan yang tidak menggunakan mata uang Rupiah. (4) Perusahaan yang tidak mendapatkan laba selama periode penelitian 2016-2020. (5) Perusahaan yang tidak mempublikasikan laporan keuangan periode penelitian 2016-2020.

Tabel 2. Penarikan Sampel

\begin{tabular}{l|c}
\hline \multicolumn{1}{c|}{ Keterangan } & Jumlah \\
\hline $\begin{array}{l}\text { Perusahaan manufaktur yang terdaftar di Bursa } \\
\text { Efek Indonesia selama periode 2016-2020. }\end{array}$ & 201 \\
\hline $\begin{array}{l}\text { Perusahaan yang tidak terdaftar selama periode } \\
\text { penelitian 2016-2020 }\end{array}$ & $(52)$ \\
\hline $\begin{array}{l}\text { Perusahaan yang tidak menggunakan mata uang } \\
\text { Rupiah }\end{array}$ & $(29)$ \\
\hline $\begin{array}{l}\text { Perusahaan yang tidak mendapatkan laba selama } \\
\text { periode penelitian 2016-2020 }\end{array}$ & $(53)$ \\
\hline Sample akhir yang dapat digunakan & $\mathbf{6 6}$ \\
\hline Jumlah observasi (5 tahun x 66 perusahaan) & $\mathbf{3 3 0}$ \\
\hline
\end{tabular}

\section{HASIL DAN PEMBAHASAN}

Tabel 3. Hasil Uji Model

\begin{tabular}{l|l|l|l}
\hline \multicolumn{1}{c|}{ Metode } & \multicolumn{1}{c|}{ Prob. } & \multicolumn{1}{c}{ Keputusan } & Keterangan \\
\hline Uji Chow & 0.0000 & H0 ditolak & Fixed effect \\
\hline Uji Hausman & 0.0018 & H0 ditolak & Fixed Effect \\
\hline
\end{tabular}

Sumber: Output regresi data panel E-views 10.0

Chow Test. Chow test adalah pengujian untuk menentukan model apakah Common Effect (CE) ataukah Fixed Effect (FE) yang paling tepat digunakan dalam mengestimasi data panel. Berdasarkan hasil uji diatas, terlihat bahwa nilai Prob. Cross-section fixed effect $F$ sebesar 0,0000 yang berarti nilainya lebih kecil dari $\alpha=0,05$, sehingga dapat disimpulkan bahwa model atau metode Fixed Effect lebih tepat digunakan dibanding model Common Effect. 
Hausman Test. Uji Hausman diartikan sebagai pengujian untuk memilih model yang terbaik yaitu antara fixed effect model dengan random effect model. Model ini akan mengestimasi data panel dimana variabel gangguan mungkin saling berhubungan antar waktu dan antar individu. Pada model Random Effect perbedaan intersep diakomodasi oleh error terms masing-masing perusahaan. Keuntungan menggunkan model Random Effect yakni menghilangkan heteroskedastisitas. Sedangkan Fixed Effect Model (FE) Model ini mengasumsikan bahwa perbedaan antar individu dapat diakomodasi dari perbedaan intersepnya. Untuk mengestimasi data panel model Fixed Effects menggunakan teknik variable dummy untuk menangkap perbedaan intersep antar perusahaan, perbedaan intersep bisa terjadi karena perbedaan budaya kerja, manajerial, dan insentif. M Uji Hausman atau yang sering disebut dengan istilah Hausman Test adalah uji yang digunakan untuk menentukan metode yang terbaik antara fixed effect ataukah random effect. Berdasarkan hasil uji diatas, terlihat bahwa nilai Cross-section random sebesar 0,0018 yang berarti nilainya lebih kecil dari $\alpha=0,05$, sehingga dapat disimpulkan bawha model atau metode Fixed Effect lebih tepat digunakan dibanding model Random Effect. Dengan demikian, metode pengujian data panel yang paling tepat digunakan adalah Metode Fixed Effect.

Uji F. Uji F diperlukan untuk mengetahui adanya pengaruh simultan dari semua variabel bebas yang dirumuskan terhadap variabel terikatnya Hasil dari tes $\mathrm{F}$ digunakan untuk memutuskan apakah faktor bebas memberikan pengaruh signifikan kepada variable terikat. Dalam pengujian ini menyambungkan antar variable bebas dan variable terikat apakah ada efek yang diberikan signifikan pada saat yang sama atau bersama-sama.

Bersadarkan hasil uji, tampaknya kemungkinan F-statistic menghasilkan nilai $0.000000<0.05$. Alhasil dari tes memperlihatkan bahwa secara serentak variable independen yaitu board size, board indenpendence, management ownership, foreign ownership, leverage, firm size dan firm performance memberikan dampak kepada agency cost sehingga model regresi tepat digunakan dalam penelitian ini. Mengingat hasil pengujian, tampaknya kemungkinan pengukuran $F$ menghasilkan nilai $0,000000<0,05$. Akibatnya hasil dari penyelidikan dalam tinjauan ini menunjukkan bahwa bersama-sama faktor otonom, khususnya Kepemilikan Administratif, Ukuran Dewan, Kebebasan Dewan, Manfaat, Ukuran Organisasi dan Penilaian teman berdampak pada keuntungan sehingga model kekambuhan dapat digunakan dalam tinjauan ini.

Uji Goodness of Fit. (uji kelayakan model) Uji Goodness of Fit atau uji kelayakan model digunakan untuk mengukur ketepatan fungsi regresi sampel dalam menaksir nilai aktual. Secara statistik uji Goodness of Fit dapat dilakukan melalui pengukuran nilai koefisien determinasi, nilai statistik $\mathrm{F}$ dan nilai statistik t yang dilakukan untuk mengukur ketepatan fungsi regresi sampel dalam menaksir nilai aktual secara statistik. Berdasarkan hasil uji goodness of fit, diperoleh nilai adjusted r-square sebesar 0.743736 . Hal ini berarti variable independen yaitu board size, board indenpendence, management ownership, foreign ownership, leverage, firm size dan firm performance mampu menjelaskan variasi dari agency cost sebesar $74.3736 \%$ dan sisanya sebesar $25.6264 \%$ menjelaskan bahwa Agency Cost dapat dipengaruhi oleh faktor lain yang tidak terdapat dalam model ini. Sehingga 
terdapat hubungan kuat antara board size, board indenpendence, management ownership, foreign ownership, leverage, firm size dan firm performance terhadap agency cost.

Uji Hipotesis. Uji hipotesis adalah sebuah proses untuk melakukan evaluasi kekuatan bukti dari sampel, dan memberikan dasar untuk membuat keputusan terkait dengan populasinya. Tujuan uji hipotesis adalah untuk memutuskan apakah hipotesis yang diuji ditolak atau diterima. Adapun multiple regresi atau regresi berganda dipakai dalam penelitian ini bertujuan menguji pengaruh dan dampak variable independen lebih dari satu terhadap variable dependen. Adapun model regresi berganda dalam penelitian ini adalah sebagai berikut:

$\mathbf{A C}=\beta_{0}+\beta_{1} \mathbf{B S}+\beta_{2} \mathbf{B I}+\beta_{3} \mathbf{M O}+\beta_{4} \mathbf{F O}+\beta_{5} \mathbf{L V}+\beta_{6} \mathbf{F S}+\beta_{7} \mathbf{F P}+\mathrm{e}$

Keterangan:

$\mathrm{AC}=$ Dividen

$\beta 0=$ Konstanta

$\beta 1-\beta 7$ = Koefisien Regresi

BS = Board Size

$\mathrm{BI}=$ Board Independent

MO = Managerial Ownership

$\mathrm{FO}=$ Foreign Ownership

$\mathrm{LV}=$ Leverage

FS $\quad=$ Firm Size

$\mathrm{FP} \quad=$ Firm Performance

Analisis Regresi Data Panel. Regresi Data Panel adalah gabungan antara data cross section dan data time series, dimana unit cross section yang sama diukur pada waktu yang berbeda. Data time-series dan data cross-section. Pada data time series, satu atau lebih variabel akan diamati pada satu unit observasi dalam kurun waktu tertentu. Sedangkan data cross-section merupakan amatan dari beberapa unit observasi dalam satu titik waktu Maka dengan kata lain, data panel merupakan data dari beberapa individu sama yang diamati dalam kurun waktu tertentu Penelitian ini memakai model analisis regresi panel guna menguji adanya pengaruh antara board size, board indenpendence, management ownership, foreign ownership, leverage, firm size dan firm performance terhadap agency cost. Berikut adalah analisis regresi:

Keuntungan melakukan regresi data panel, antara lain: (1) Pertama, dapat memberikan peneliti jumlah pengamatan yang besar, meningkatkan degree of freedom (derajat kebebasan), data memiliki variabilitas yang besar dan mengurangi kolinieritas antara variabel penjelas, dimana dapat menghasilkan estimasi ekonometri yang efisien. (2) Kedua, panel data dapat memberikan informasi lebih banyak yang tidak dapat diberikan hanya oleh data cross section atau time series saja. (3) Ketiga, panel data dapat memberikan penyelesaian yang lebih baik dalam inferensi perubahan dinamis dibandingkan data cross section. 
$\mathrm{AC}=5,724448+0,112892 \mathrm{BS}-0,001337 \mathrm{BI}+0,010737 \mathrm{MO}-0,001255 \mathrm{FO}-0,002647 \mathrm{LV}$ $-0,809783 \mathrm{FS}+0,008106 \mathrm{FP}$.

Uji T. Uji T yang pertama kali dikembangkan oleh William Seely Gosset. Tes $\mathrm{t}$ atau Uji $\mathrm{t}$ adalah uji statistik yang digunakan untuk menguji kebenaran atau kepalsuan hipotesis nol digunakan dalam mengukur pengaruh koefisien regresi dari variabel independen yang terdiri dari board size, board indenpendence, management ownership, foreign ownership, leverage, firm size dan firm performance terhadap variabel dependen yaitu agency cost.

Tabel 5. Uji T

\begin{tabular}{l|c|c|c}
\hline \multirow{2}{*}{ Variabel Independen } & \multicolumn{3}{|c}{ Variabel Dependen } \\
\cline { 2 - 4 } & \multicolumn{3}{|c}{ DIV } \\
\cline { 2 - 4 } & Koefisien & Probabilitas & Kesimpulan \\
\hline Konstanta & 5.724448 & - & Tidak Signifikan \\
\hline BSIZE & 0.112892 & 0.3331 & Tidak Signifikan \\
\hline BI & -0.001337 & 0.8952 & Tidak Signifikan \\
\hline MO & 0.010737 & 0.6489 & Tidak Signifikan \\
\hline FO & -0.001255 & 0.8603 & Negatif Signifikan \\
\hline LV & -0.002647 & 0.0248 & Negatif Signifikan \\
\hline FS & -0.809783 & 0.0446 & Tidak Signifikan \\
\hline
\end{tabular}

Board Size (BSIZE) yakni Board size atau ukuran dewan adalah jumlah personel dewan direksi dan komisaris dalam suatu perusahaan, dalam penelitian ini memiliki nilai probabilitas sebesar $0.3331>0,05$ (alpha 5\%) yang menunjukan pengaruh tidak signifikan. Hasil penelitian ini menyimpulkan tidak terdapat pengaruh signifikan antara Board Size terhadap agency cost.

Board Independence (BI) Board independent merupakan salah satu variabel dari struktur corporate governance internal yang diperkirakan akan berpengaruh terhadap agency cost. Board independent dalam studi ini diproksi oleh Persentase jumlah anggota dewan komisaris independen dari keseluruhan jumlah anggota dewan komisaris memiliki nilai probabilitas sebesar $0.8952>0,05$ (alpha 5\%) yang menunjukan pengaruh tidak signifikan. Besarnya koefisien sebesar -0.001337 . Hasil penelitian ini menyimpulkan adanya pengaruh negatif dan tidak signifikan antara Board Independence terhadap Agency Cost.

Managerial Ownership (MO) Managerial ownership merupakan salah satu mekanisme yang digunakan untuk meminimalkan terjadinya konflik keagenan (agency conflict). Semakin besar managerial ownership dalam suatu badan usaha, maka manajemen akan meningkatkan kinerjanya untuk mencapai kepentingan pemegang saham dan kepentingannya sendiri saham yang dimiliki oleh manajemen perusahaan, termasuk dewan komisaris dan direksi, yang turut aktif dalam pengambilan keputusan perusahaan, pada penelitian ini memiliki nilai probabilitas sebesar $0.6489>0,05$ (alpha 5\%) yang menunjukan pengaruh tidak signifikan. Besarnya koefisien sebesar 0.010737. Hasil 
penelitian ini menyimpulkan adanya pengaruh positif dan tidak signifikan antara Managerial Ownership terhadap Agency Cost.

Foreign Ownership (FO) Foreign ownership merupakan salah satu mekanisme yang digunakan untuk meminimalkan terjadinya konflik keagenan (agency conflict). Semakin besar foreign ownership dalam suatu badan usaha, maka manajemen akan meningkatkan kinerjanya untuk mencapai kepentingan pemegang saham dan kepentingannya sendiri saham yang dimiliki oleh manajemen perusahaan, termasuk dewan komisaris dan direksi, yang turut aktif dalam pengambilan keputusan perusahaan, pada penelitian ini memiliki nilai probabilitas sebesar $0.8603>0,05$ (alpha 5\%) yang menunjukan pengaruh tidak signifikan. Besarnya koefisien sebesar -0.001255 . Hasil penelitian ini menyimpulkan adanya pengaruh negatif dan tidak signifikan antara Foreign Ownership terhadap Agency Cost.

Leverage (LV) Leverage memiliki nilai probabilitas sebesar $0.0248<0,05$ (alpha 5\%) yang menunjukan pengaruh signifikan. Besarnya koefisien sebesar -0.002647 . Hasil penelitian ini menyimpulkan terdapat pengaruh negatif dan signifikan antara Leverage terhadap agency Cost. Perbandingan yang tepat atas pendapatan dan biaya tergambar dalam laporan laba rugi. Penyajian laba melalui laporan tersebut merupakan fokus kinerja perusahaan yang penting. Kinerja perusahaan merupakan hasil dari serangkaian proses dengan mengorbankan berbagai sumber daya. Adapun salah satu parameter penilaian kinerja perusahaan tersebut adalah pertumbuhan laba.

Firm Size (FS) yaitu ukuran perusahaan adalah skala besar kecilnya perusahaan yang ditentukan dari total aktiva, atau bisa juga disebut suatu skala dimana dapat diklasifikasikan besar kecilnya suatu perusahaadari penelitian ini memiliki nilai probabilitas sebesar 0.0446 $<0,05$ (alpha 5\%) yang menunjukan pengaruh signifikan. Besarnya koefisien sebesar 0.809783 . Hasil penelitian ini menyimpulkan adanya pengaruh negatif dan signifikan antara Firm Size terhadap agency Cost. Firm size berpengaruh signifikan terhadap agency Cost.

Firm Performance (FP) yakni kinerj perusahaan menjadi pendorong untuk biaya agensi. Pada penelitian ini, hasilnya memiliki nilai probabilitas sebesar 0,1168 >0,05 (alpha 5\%) yang menunjukan pengaruh tidak signifikan. Besarnya koefisien sebesar 0.008106. Hasil penelitian ini menyimpulkan tidak terdapat pengaruh signifikan antara Firm Performance terhadap agency Cost.

\section{KESIMPULAN}

Penelitian ini bertujuan menguji pengaruh board size, board indenpendence, management ownership, foreign ownership, governance ownership, leverage, firm size dan firm performance terhadap variable dependen yaitu agency Cost perusahaan sektor manufaktur yang terdaftar di Bursa Efek Indonesia pada tahun 2016-2020 dengan jumlah sample 66 perusahaan. Berdasarkan penelitian yang telah dilakukan, Board Size memiliki pengaruh positif dan tidak signifikan terhadap agency Cost, Board Independence memiliki 
pengaruh negatif dan tidak signifikan terhadap agency Cost, Managerial Ownership memiliki pengaruh positif dan tidak signifikan terhadap agency Cost, Foreign Ownership memiliki pengaruh negatif dan tidak signifikan terhadap agency Cost, leverage memiliki pengaruh negatif dan signifikan terhadap agency Cost, Firm Size memiliki pengaruh negatif dan signifikan terhadap agency Cost, firm performance tidak memiliki pengaruh terhadap agency Cost.

Implikasi Manajerial. Mengingat simpulan yang diperoleh dari penelitian terdapat implikasi manajerial yang bisa digunakan dalam bisnis. Implikasi manajerial tersebut adalah:

Bagi prinsipal, diharapkan untuk tetap memantau pelaksanaan good corporate governance sebagai upaya meminimalkan kerugian yang muncul akibat dari tindakan dan kebijakan yang dibuat agen.

Bagi agen, disarankan untuk konsisten dalam menerapkan good corporate governance sehingga dapat memberi kepercayaan pada pihak prisipal bahwa tindakan agen sesuai dengan tujuan perusahaan.

Keterbatasan Penelitian. Penelitian yang dilakukan dan diuji mempunyai beberapa keterbatasan dalam penelitian sehingga hasil yang diselesaikan masih memiliki banyak kekurangan. Keterbatasan dalam penelitian yaitu penelitian ini hanya menggunakan sampel dari perusahaan sektor manufaktur dengan sampel sebanyak 66 perusahaan, laporan keuangan yang digunakan hanya perusahaan yang menggunakan mata uang rupiah, waktu dalam penelitian hanya lima tahun yaitu dari 2016-2020, variabel yang dipakai dalam penelitian ini terbatas yaitu terdiri dari Variabel independen yang digunakan yaitu board size, board indenpendence, management ownership, foreign ownership, dan governance ownership serta leverage, firm size, dan firm performance sebagai variabel kontrol terhadap agency cost sebagai variabel dependen.

Saran. Mengingat penjelasan keterbatasan dari penelitian di atas, penelitian ini dapat memberikan ide-ide untuk ilmuwan tambahan di bidang yang sama untuk memikirkan halhal seperti, Melakukan penelitian pada sektor lain seperti pada Properti, Real Estate dan Konstruksi Bangunan secara keseluruhan yang terdaftar di Bursa Efek Indonesia. Mengembangkan lingkup penelitian ini dengan menggunakan variabel lain yang dapat mempengaruhi agency cost.

\section{DAFTAR PUSTAKA}

Čalopa, M. K., Kokotec, I. Đ., and Kokot, K. (2020). Impact of board size and ownership concentration on agency costs: Evidence for croatian companies. Zbornik Radova Ekonomskog Fakultet Au Rijeci, 38(2). https://doi.org/10.18045/zbefri.2020.2.521.

Chaudhary, P. (2021). Agency costs, board structure and institutional investors: case of India. Asian Journal of Accounting Research, ahead-of-print(ahead-of-print). https://doi.org/10.1108/ajar-12-2020-0130.

Choi, Y. M., and Park, K. (2019). Foreign ownership, agency costs, and long-term firm 
growth: Evidence from Korea. Sustainability (Switzerland), 11(6). https://doi.org/10.3390/su10021599.

Febrianny, C. I., Purwohedi, U., dan Handarini, D. (2020). Pengaruh Profitabilitas, Kepemilikan Asing, dan Keberadaan Wanita Dalam Dewan Direksi Terhadap Nilai Filantropi Perusahaan. Jurnal Akuntansi, Perpajakan, Dan Auditing, 1(1).

Gray, P., Koh, P. S., and Tong, Y. H. (2019). Accruals quality, information risk and cost of capital: Evidence from Australia. Journal of Business Finance and Accounting, 36(12). https://doi.org/10.1111/j.1468-5957.2008.02118.x.

Hamdan, A. M. (2018). Dividend policy, agency costs and board independence. International Journal of Critical Accounting, 10(1). https://doi.org/10.1504/ijca.2018.10012244.

Huu Nguyen, A., Thuy Doan, D., and Ha Nguyen, L. (2020). Corporate Governance and Agency Cost: Empirical Evidence from Vietnam. Journal of Risk and Financial Management, 13(5). https://doi.org/10.3390/jrfm13050103.

Indriastuti, M., Kartika, I., and Najihah, N. (2021). Financial Distress Prediction: The Ownership Structure and Management Agency Cost. The Indonesian Journal of Accounting Research, 24(02). https://doi.org/10.33312/ijar.514.

Krisnauli; Hadiprajitno, P. B. (2014). Struktur Kepemilikan Terhadap Agency Cost ( Studi Empiris pada Perusahaan Manufaktur yang Terdaftar di BEI Tahun 2010-2012 ). Diponegoro Journal Of Accounting, 3(2), 1-13.

Kusumasari, R. D., Fadilah, S., and Sukarmanto, E. (2018). Pengaruh pajak, kepemilikan asing, dan ukuran perusahaan terhadap transfer pricing (studi empiris pada perusahaan manufaktur yang terdaftar di bursa efek Indonesia periode 2012-2016). Prosiding Akuntansi, 4(2).

Mappanyukki, R., Prakoso, H. D., and Irwandi, S. A. (2016). The Impact of Free Cash Flow and Good Corporate Governance on Earning Management of Banking Companie Listed on The Indonesian Stock Exchange. Research Journal of Finance and Accounting, 7(20).

Melmusi, Z. (2016). Pengaruh Pajak, Mekanisme Bonus, Kepemilikan Asing dan Ukuran Perusahaan Terhadap Transfer Pricing Pada Perusahaan Yang Tergabung Dalam Jakarta Islamic Index dan Terdaftar di Bursa Efek Indonesia Periode 2012-2016. Jurnal Ekobistek Fakultas Ekonomi, 5(2).

Prananda, R. 'Aisy, dan Triyanto, D. N. (2020). Pengaruh Beban Pajak, Mekanisme Bonus, Exchange Rate, Dan Kepemilikan Asing Terhadap Indikasi Melakukan Transfer Pricing. Nominal: Barometer Riset Akuntansi Dan Manajemen, 9(2). https://doi.org/10.21831/nominal.v9i2.30914.

Pujiati, D., dan Widanar, E. (2019). Pengaruh Struktur Kepemilikan Terhadap Nilai Perusahaan Keputusan Keuangan Sebagai Variabel Intervening. Jurnal Ekonomi Bisnis \& Akuntansi Ventura, 12(1).

Rahyuningsih, R., dan Ayem, S. (2020). Pengaruh leverage dan kepemilikan manajerial terhadap manajemen laba dengan agency cost sebagai variabel intervening pada perusahaan manufaktur. Kajian Bisnis Sekolah Tinggi Ilmu Ekonomi Widya Wiwaha, 28(2). https://doi.org/10.32477/jkb.v28i2.210.

Retnoningsih, S., and Mahanani, S. (2019). Influence of Financial Performance, Value of 
Company, Corporate Governance Mechanism For Executive Compensation. https://doi.org/10.2991/iscogi-17.2019.42.

Sayidah, N. (2017). Pengaruh Kualitas Corporate Governance Terhadap Kinerja Perusahaan Publik. Jurnal Akuntansi.

Singh, M., and Davidson, W. N. (2018). Agency Costs, Ownership Structure And

Corporate Governance Mechanisms. Journal of Banking and Finance, 27(5). https://doi.org/10.1016/S0378-4266(01)00260-6.

Structure, P. O., Flow, F. C., Shael, E., \& Murhadi, W. R. (n.d.). Corporate Governance Terhadap Biaya Keagenan. 1-93.

Thi Tuyet Mai Nguyen, and Elaine Evans, M. L. (2017). Article information: Independent directors, ownership concentration and firm performance in listed companies Pacific Accounting Review.

Yusuf, A., dan Said, D. (2018). Hubungan Antara Modal Intelektual Dengan Nilai Pasar Dan Kinerja Keuangan Di Perusahaan Publik Indonesia The Relationship between Intellectual Capital, Market Value and Financial Performance in Indonesian Public Companies. Jurnal Analisis, 2(1). 